\title{
The program of physical training of servicemen to a qualification examination on the right to wear the "Beret with honors"
}

\author{
Anatskyi R.V. ${ }^{1 \mathrm{ABDE}}$, Kolomiitseva O.E. ${ }^{2 \mathrm{ABCDE}}$, Liubchich R.E. ${ }^{3 \mathrm{ABDE}}$ \\ ${ }^{1}$ The department of physical training and sport, National Academy of the National Guard of Ukraine, Ukraine \\ ${ }^{2}$ The department of physical education №1, Yaroslav Mudryi National Law University; Ukraine \\ ${ }^{3}$ The department of physical training and sport, National Academy of the National Guard of Ukraine, Ukraine
}

Authors' Contribution: A - Study design; B - Data collection; C - Statistical analysis; D - Manuscript Preparation; E - Funds Collection.

\begin{abstract}
Purpose: $\quad$ To develop the author's program of physical training of servicemen to a qualification examination on the right to wear "The Beret with honors" and to check its efficiency.

Material: $\quad$ The perspective contingent for participation in an examination in number of 20 people at the age of 19-23 years participated in the researches. Motive tests were used for determination of level of preparedness: run of $10 \mathrm{~km}$, passing of the general combat course; grenade throwing; time of performance of complex power exercise: 30 squats, 30 bendings extensions of hands in an emphasis lying, 30 raising of legs lying, turn over of a rubber tire of $30 \mathrm{~m}$. Time of dismantling-assembly of weapon, filling of magazine and finishing of $30 \mathrm{~m}$ were fixed in fire preparation. Defeat of the target was fixed in points when firing. Basic provisions of the author's program of training: duration of 21 day; Monday - Friday on two trainings, Saturday - one training and recovery actions, Sunday - rest; a method of performance of exercises - continuous; trainings took place in full combat equipment; the main attention was paid to development of the general endurance in the morning and the whole other work was performed against the background of the general exhaustion.

Results: Use of the author's technique in 21 days of training allowed: to increase the level of the general endurance by $11,5 \%$, the level of power endurance by $4,2 \%$, the level of high-speed and power abilities and dexterity by $9,9 \%$; the level of preparedness for aimed fire by $17,3 \%$.

Conclusions: The accelerated, three-week training program with complex use of power exercises, aerobic load, fighting sparrings and service weapon firing brought positive results. Thus, the level of professional preparedness of cadets for performing the set task was increased.

Keywords: $\quad$ servicemen, examination, the beret with honors, endurance, training program.
\end{abstract}

\section{Introduction}

The main task when training the military personnel always was and is an increase in level of professional preparedness $[1,2]$. This problem is solved during training of cadets in higher education institution and directly on places of constant service [3-5]. This process is difficult and many-sided, has relevance among scientists of the whole world [6, 7]. The Ukrainian system of training of servicemen even more often is guided by the western technologies of initialization of fighters of the high level. In this regard a row of the actions, which are directed to creation of an incentive to independent increase in the level of professional and moral and strong-willed qualities at servicemen, detection of the best servicemen ready to discharge official and fighting tasks in critical situations and extraordinary conditions is carried out in the ranks of the National Guard of Ukraine.

Battalion commanders use different methods of the level of readiness assessment in practice of physical training of the soldier [8,9]. Using run 1.5 miles, researchers try to predict risk of traumatism and exhaustion level at the initial stage of training of recruits of the British army [10]. Scientific research is devoted to the range of problems of combination of two physiologically opposite abilities: force and endurance in physical training of the military personnel [11, 12]. Authors consider that the high level of

(C) Anatskyi R.V., Kolomiitseva O.E., Liubchich R.E., 2018

doi:10.15561/20755279.2018.0601 aerobic fitness can threaten achievement of the maximum force and increase traumatism level.

The militarized cross with firing and grenade throwing demands from servicemen of ability to overcome the considerable physical fatigue for performance of the set combat task. Such exercise is a difficult element in the system of physical training of staff of the today's army $[13,14]$. The modern military and application-oriented all-round is considered a combinative look as each of its types can significantly affect the general result of performance of the task $[15,16]$. Besides, military allround differs not only the content of exercises of which consists, but also organization and support of trainings and competitions [5].

The right to participate in the examination on the right to wear the beret with honors is granted not to each serviceman. There is a number of requirements imposed to candidates, basic of which are: the serviceman has to do military service more than 1,5 years, have high grades on the main objects of combat and special training; doesn't have disciplinary punishments and to be characterized positively on service. An important factor of successful passing an examination is psychological reliability of cadets, in particular moral and strong-willed and functional reliability $[17,18]$.

The process of preparation for this test is difficult and many-sided. The complexity is caused by need of the organization of training camps during educational 
process, existence of necessary material resources, enough cartridges and additional subsistence support. The versatility of this preparation is caused by ability of specialists in physical and fire training, hand-to-hand fight in common to plan and carry out preparation according to all sections qualitatively and without damage each other [13]. By recognition of the acting members of spetsnaz and their instructors, in training of applicants for the right to wear the maroon beret, continuous increase in the level of endurance and statement of breath is especially important $[1,19]$.

An examination on the right to wear the beret with honors is exclusively difficult stage of vocational training of servicemen. It is a rather new type of initialization of fighters in the modern National Guard of Ukraine, the technique of preparation for which, in the modern scientific and methodical literature, is not practically displayed. It allows to say about the relevance of our researches.

In this regard the purpose of our researches became to develop the authoring program of physical training of servicemen to a qualification examination on the right to wear «The Beret with honors» and to check its efficiency.

\section{Material and methods}

Participants. Servicemen - the perspective contingent for participation in an examination in number of 20 people at the age of 19-23 years participated in researches.

Research Design. Motive tests were used for determination of the level of preparedness of servicemen for passing of an examination: run of $10 \mathrm{~km}$, passing of the general combat obstacle course; grenade throwing; time of performance of complex power exercise: 30 squats, 30 bendings extensions of hands in an emphasis lying, 30 raising of legs lying, turn over of a rubber tire of $30 \mathrm{~m}$. Time of dismantling-assembly of weapon, filling of magazine and finishing of $30 \mathrm{~m}$ was fixed in firearms training. Defeat of the target was fixed in points when firing.

The qualified examination in this modification consisted of the following stages which servicemen passed in full combat equipment according to the order of the commander of the National Guard of Ukraine:

1. battle march till $12 \mathrm{~km}$ with overcoming artificial and natural obstacles and grenade throwing on range not less than $30 \mathrm{~m}$;

2. overcoming the general combat obstacle course;

3. stage of strength training which includes performance of the following exercises on 30 times: squats with a bag weighing $30 \mathrm{~kg}$, lifting of legs lying «bottom press», bending extension of hands in an emphasis lying; turn over of a rubber tire of $30 \mathrm{~m}$;

4. stage of implementation of standards for fire preparation (incomplete dismantling-assembly of regular model weapon and filling of magazine) + finishing by run of $30 \mathrm{~m}$;

5. firing from a military weapon (Kalashnikov rifle $\mathrm{AK}$ and Makarov gun PM);

Table 1. The program of training of cadets for the qualified examination on the right to wear the beret with honors

\begin{tabular}{|c|c|}
\hline $\begin{array}{l}\text { Day of the } \\
\text { week }\end{array}$ & Content of training \\
\hline \multirow{3}{*}{ Mon. } & $\begin{array}{l}\text { Cross preparation of } 12 \mathrm{~km} \text {, heart rate (HR) in the range of } 140-150 \mathrm{bpm} \text {. Overcoming an } \\
\text { obstacle course } 2 \text { times by the continuous method. Combined firing problem. }\end{array}$ \\
\hline & $\begin{array}{l}\text { Run of } 3 \mathrm{~km} \text { at moderate speed, warm-up, and force preparation: } 3 \text { exercises with overcoming } \\
\text { own gravity }+1 \text { exercise with weighting till } 30 \mathrm{~kg} \text { on } 30 \text { repetitions by } 2 \text { series. Combined firing } \\
\text { problem. }\end{array}$ \\
\hline & $\begin{array}{l}\text { Cross preparation of } 10 \mathrm{~km}, \mathrm{HR} \text { in the range of } 150-160 \mathrm{bpm} \text {, overcoming a blockage from logs } \\
\text { on each kilometer. Combined firing problem. }\end{array}$ \\
\hline Tues. & $\begin{array}{l}\text { Run of } 4 \mathrm{~km} \text {, warm-up, strength training: } 3 \text { exercises with overcoming own gravity }+1 \text { exercise } \\
\text { with weighting till } 30 \mathrm{~kg} \text { on } 30 \text { repetitions by } 2 \text { series. Combined firing problem. Working off of } \\
\text { technical actions and combinations from hand-to-hand fight. }\end{array}$ \\
\hline \multirow[t]{3}{*}{ Wed. } & $\begin{array}{l}\text { Cross preparation of } 12 \mathrm{~km}, \mathrm{HR} \text { in the range of } 140-150 \mathrm{bpm} \text {, on the } 2 \mathrm{nd}, 4 \mathrm{th}, 6 \text { th } \mathrm{km} \\
\text { overcoming an obstacle course. Combined firing problem. }\end{array}$ \\
\hline & Run of 4 km. Stretch. Hopping exercises. Combined firing problem. \\
\hline & Run of 4 km, warm-up. Combined firing problem. \\
\hline Thur. & $\begin{array}{l}\text { Warm-up, strength training: } 3 \text { exercises with overcoming own gravity }+1 \text { exercise with weighting } \\
\text { till } 30 \mathrm{~kg} \text { on } 30 \text { repetitions by } 3 \text { series. } \\
\text { Working off of technical actions and combinations from hand-to-hand fight together with } \\
\text { training sparrings. }\end{array}$ \\
\hline \multirow[t]{2}{*}{ Fr. } & $\begin{array}{l}\text { Cross preparation of } 12 \mathrm{~km}, \mathrm{HR} \text { in the range of } 140-150 \mathrm{bpm} \text {, on the } 2 \mathrm{nd}, 4 \mathrm{th}, 6 \mathrm{th} \mathrm{km} \text { power } \\
\text { block: } 3 \text { exercises with overcoming own gravity }+1 \text { exercise with weighting till } 30 \mathrm{~kg} \text { on } 30 \\
\text { repetitions by one series. Combined firing problem. }\end{array}$ \\
\hline & Run of $3 \mathrm{~km}$, warm-up, working off of elements of an obstacle course. Combined firing problem. \\
\hline Sat. & Cross preparation of $15 \mathrm{~km}, \mathrm{HR}$ in the range of $150-160 \mathrm{bpm}$. Stretching. \\
\hline
\end{tabular}


Continuation Table 1.

\begin{tabular}{|c|c|}
\hline $\begin{array}{l}\text { Day of the } \\
\text { week }\end{array}$ & Content of training \\
\hline \multirow[t]{2}{*}{ Mon. } & $\begin{array}{l}\text { Cross preparation of } 10 \mathrm{~km}, \mathrm{HR} \text { in the range of } 150-160 \mathrm{bpm} \text {, on } 3 \mathrm{~km} \text { overcoming an obstacle } \\
\text { course, overcoming a blockage from logs and power block: } 3 \text { exercises with overcoming own } \\
\text { gravity }+1 \text { exercise with weighting till } 30 \mathrm{~kg} \text { on } 30 \text { repetitions by one series. Combined firing } \\
\text { problem. }\end{array}$ \\
\hline & $\begin{array}{l}\text { Run of } 4 \mathrm{~km} \text {, warm-up. Combined firing problem. Working off of technical actions and } \\
\text { combinations from hand-to-hand fight. }\end{array}$ \\
\hline \multirow{2}{*}{ Tues. } & $\begin{array}{l}\text { Cross preparation of } 12 \mathrm{~km}, \mathrm{HR} \text { in the range of } 140 \mathrm{bpm} \text {, on each kilometer overcoming: a } \\
\text { blockage from logs, labyrinth on an obstacle course, destroyed steps. Combined firing problem. }\end{array}$ \\
\hline & $\begin{array}{l}\text { Run of } 4 \mathrm{~km} \text {, warm-up, strength training: } 3 \text { exercises with overcoming own gravity }+1 \text { exercise } \\
\text { with weighting till } 30 \mathrm{~kg} \text { on } 30 \text { repetitions by } 2 \text { series. Combined firing problem. }\end{array}$ \\
\hline \multirow[t]{2}{*}{ Wed. } & $\begin{array}{l}\text { Cross preparation of } 10 \mathrm{~km}, \mathrm{HR} \text { in the range of } 150-160 \mathrm{bpm} \text {, warm-up. Combined firing } \\
\text { problem. }\end{array}$ \\
\hline & Run of $4 \mathrm{~km}$, warm-up, run $5 \times 100 \mathrm{~m}$ through $100 \mathrm{~m}$ of jogging. Combined firing problem. \\
\hline & Run of 4 km, warm-up. Combined firing problem. \\
\hline Thur. & $\begin{array}{l}\text { Warm-up. Working off of technical actions and combinations from hand-to-hand fight together } \\
\text { with training sparrings. Strength training: } 4 \text { exercises with overcoming own gravity }+2 \text { exercises } \\
\text { with weighting till } 30 \mathrm{~kg} 3 \text { series on } 30 \text { repetitions. }\end{array}$ \\
\hline \multirow[t]{2}{*}{ Fr. } & $\begin{array}{l}\text { Cross preparation of } 10 \mathrm{~km}, \mathrm{HR} \text { in the range of } 150-160 \mathrm{bpm} \text {, on } 4 \mathrm{~km} \text { overcoming an obstacle } \\
\text { course, power block: } 3 \text { exercises with overcoming own gravity }+1 \text { exercise with weighting till } 30 \\
\mathrm{~kg} \text { on } 30 \text { repetitions by one series. }\end{array}$ \\
\hline & Run of 4 km, warm-up. Combined firing problem. \\
\hline Sat. & Cross preparation of $15 \mathrm{~km}, \mathrm{HR}$ in the range of $120 \mathrm{bpm}$. Warm-up. Stretching. Training sparrings. \\
\hline \multirow[t]{2}{*}{ Mon. } & $\begin{array}{l}\text { Cross preparation of } 10 \mathrm{~km}, \mathrm{HR} \text { in the range of } 150-160 \mathrm{bpm} \text { : on the } 1 \mathrm{st} \text { and } 3 \mathrm{rd} \mathrm{km} \text { overcoming } \\
\text { an obstacle course; on the } 2 \text { nd and } 4 \text { th } \mathrm{km} \text { performance of power block: } 3 \text { exercises with } \\
\text { overcoming own gravity }+1 \text { exercise with weighting till } 30 \mathrm{~kg} \text { on } 30 \text { repetitions. }\end{array}$ \\
\hline & Run of 4 km, warm-up. Combined firing problem. \\
\hline \multirow{2}{*}{ Tues. } & $\begin{array}{l}\text { Cross preparation of } 10 \mathrm{~km}, \mathrm{HR} \text { in the range of } 120 \mathrm{bpm} \text {. Run } 5 \times 100 \mathrm{~m} \text { after } 100 \mathrm{~m} \text { of jogging. } \\
\text { Combined firing problem. }\end{array}$ \\
\hline & $\begin{array}{l}\text { Run of } 4 \mathrm{~km} \text {, warm-up. Power preparation: } 5 \text { exercises with weighting on } 30 \text { repetitions by three } \\
\text { series. Combined firing problem. }\end{array}$ \\
\hline & Cross preparation of $12 \mathrm{~km}, \mathrm{HR}$ in the range of $140-150 \mathrm{bpm}$. Combined firing problem. \\
\hline Wed. & $\begin{array}{l}\text { Run of } 4 \mathrm{~km} \text {, warm-up. Overcoming an obstacle course }-3 \text { repetitions. Working off of technical } \\
\text { actions and combinations from hand-to-hand fight together with training sparrings. }\end{array}$ \\
\hline \multirow{2}{*}{ Thur. } & $\begin{array}{l}\text { Run of } 4 \mathrm{~km} \text {, warm-up. Strength training: } 5 \text { exercises with weighting till } 30 \mathrm{~kg}+2 \text { exercises with } \\
\text { overcoming own gravity on } 30 \text { repetitions by } 3 \text { series. Combined firing problem. }\end{array}$ \\
\hline & $\begin{array}{l}\text { Working off of technical actions and combinations from hand-to-hand fight together with } \\
\text { training sparrings. }\end{array}$ \\
\hline \multirow[t]{2}{*}{ Fr. } & $\begin{array}{l}\text { Cross preparation of } 6 \mathrm{~km}, \mathrm{HR} \text { in the range of } 120-130 \mathrm{bpm} \text {, warm-up. Strength training: } 3 \\
\text { exercises with overcoming own gravity }+1 \text { exercise with weighting till } 30 \mathrm{~kg} \text { on } 30 \text { repetitions by } \\
3 \text { series. Combined firing problem. }\end{array}$ \\
\hline & Working off of technical actions and combinations from hand-to-hand fight. \\
\hline \multirow[t]{2}{*}{ Sat. } & $\begin{array}{l}\text { Cross preparation of } 6 \mathrm{~km} \text { in the range of } 120-130 \mathrm{bpm} \text {, warm-up. Stretching. Strength training: } \\
3 \text { exercises with overcoming own gravity }+1 \text { exercise with weighting till } 30 \mathrm{~kg} 3 \text { series on } 30 \\
\text { repetitions. Combined firing problem. }\end{array}$ \\
\hline & $\begin{array}{l}\text { Use of technical-tactical exercises, directed to unification of personal arsenal motor skills of } \\
\text { hand-to-hand fight. }\end{array}$ \\
\hline Sun. & $\begin{array}{l}\text { Run of } 3 \mathrm{~km} \text {, warm-up. Strength training: } 3 \text { exercises with overcoming own gravity }+1 \text { exercise } \\
\text { with weighting till } 30 \mathrm{~kg} 3 \text { series on } 30 \text { repetitions. Combined firing problem. }\end{array}$ \\
\hline
\end{tabular}


6. hand-to-hand fight.

According to the above-mentioned stages the program of training, which was carried out 21 days, was created. The abstract of the program is presented in tab. 1. From Monday till Friday servicemen had two trainings, on Saturday - one training and recovery actions, on Sunday - rest.

Morning training began at 9:00 with statement of tasks and instructing in security measures, the second training began at 15:30. The continuous method was used as the main method of performance of work regardless of its orientation. For formation of strong-willed qualities of cadets, accustomings to severe conditions of examination of training took place in full equipment. They are: weapon of $\mathrm{AK}$ with four magazines, $9 \mathrm{~mm}$ gun with two magazines, a gas mask, the unloading and zone system and a bullet-proof vest of the IV class of protection «the Corsair M-3M» with hinged equipment (a bag for magazines, a holster, the medical first-aid kit, a bag for dumping of magazines, a drinking flask - volume not less than 0.751 ), a safety kevlar helmet by type the Helmet$1 \mathrm{M})$.

The program of the qualified examination can be modified and include various types of exercises, in their various sequence, with various volume of load. In the presented modification examination on the right to wear the beret with honors includes the exercises provided by the program of training of cadets. For example, standards for grenade throwing, overcoming the general obstacle course, power preparation are given cadets throughout the entire period of training. In this regard it was paid less attention to these exercises during the trainings. The technical aspect of preparation when passing separate parts of the obstacle course, such as was maintained: the destroyed bridge and the destroyed ladder, labyrinth. The level of strength training, including in grenade throwing was supported.

Statistical Analysis. In this study, to obtain the statistical results, SPSS package was used. The means and standard deviation of the measurements and tested variables of all subjects were calculated. Values under $\mathrm{p}<0.05$ were accepted as statistically significant. Expert poll of 18 leading teachers with a rating scale from 1 till 10 was used. Weighting coefficient was calculated by the formula:

$$
k_{B_{i}}=\frac{\sum_{i=1}^{N} M_{i j}}{\sum_{i=1}^{n} \sum_{j=1}^{N} M_{i j}},
$$

where $\mathrm{n}$ - quantity of indicators (types of training);

$\mathrm{N}$ - number of experts;

$\mathrm{M}_{\mathrm{ij}}$ - weighting assessment $i$ indicator in points, given $j$ by the expert.

\section{Results}

The ratings of types of training for passing the military personnels' examination on the right of wearing "The beret with honors" were estimated by the group of 18 experts. Results of processing of ratings are presented in fig. 1. Weighting coefficients specify the degree of influence of each of types of training on the final result of examination.

According to experts, results of battle march on $12 \mathrm{~km}$ have the most powerful degree of influence on a result of examination. Fighting sparring -0.22 and strength training -0.19 are the next on the degree of influence on the general result of examination. Further there are stages: firing -0.17 and overcoming an obstacle course -0.15 .

Results of the researches of level of preparedness of servicemen are presented in tab. 2. It should be noted that the initial level of results of run on $12 \mathrm{~km}$ is rather

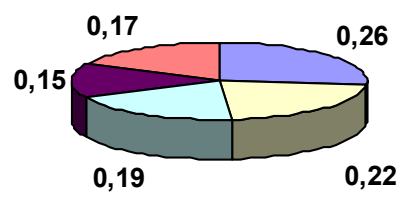

$\square$ battle march $12 \mathrm{~km} \square$ fighting sparring $\square$ strength training $\square$ high-speed strength training $\square$ firing

Fig. 1. Results of expert estimation of weighting coefficients of types of training

Table 2. Results of training of cadets for examination on the right to wear the beret with honors

\begin{tabular}{|c|c|c|c|c|c|c|c|c|}
\hline \multirow{2}{*}{ Types of exercises } & \multicolumn{2}{|c|}{ Initial level } & \multicolumn{2}{|c|}{ Intermediate level } & \multicolumn{2}{|l|}{ Final level } & \multirow{2}{*}{$t_{1-3}$} & \multirow[b]{2}{*}{$p_{1-3}$} \\
\hline & $x_{1}$ & $\sigma_{1}$ & $x_{2}$ & $\sigma_{2}$ & $x_{3}$ & $\sigma_{3}$ & & \\
\hline battle march $12 \mathrm{~km}$, min, sec & 68.52 & 2.24 & 63.8 & 3.2 & 60.2 & 2,83 & 2,3 & $<0.05$ \\
\hline obstacle course, $\min , \mathrm{sec}$ & 3.29 & 0.08 & 3.26 & 0.08 & 3.2 & 0.09 & 0.9 & $>0.05$ \\
\hline $\begin{array}{l}\text { complex power exercise ( } 4 \\
\text { exercises), min }\end{array}$ & 4.08 & 0.06 & 3.64 & 0.15 & 3.5 & 0.03 & 9,6 & $<0.01$ \\
\hline grenade throwing, m & 31.41 & 1.55 & 31.91 & 1.65 & 32.28 & 1,21 & 0.44 & $>0.05$ \\
\hline fire preparation, $\min , \mathrm{sec}$ & 2.09 & 0.32 & 1.54 & 0.15 & 1.52 & 0.21 & 1,5 & $>0.05$ \\
\hline $\begin{array}{l}\text { firing (AK-1, PM), from } 250 \\
\text { points }\end{array}$ & 140.16 & 33.77 & 153.83 & 38.22 & 164.17 & 15,83 & 0.64 & $>0.05$ \\
\hline
\end{tabular}


Table 3. Results of servicemen who passed the qualification examination for the right to wear the beret with honors

\begin{tabular}{lllll}
\hline \multirow{2}{*}{ Types of exercises } & \multicolumn{2}{c}{ Final results of preparation } & \multicolumn{2}{c}{ Results of examination } \\
& $\mathbf{X}_{\mathbf{1}}$ & $\boldsymbol{\sigma}_{\mathbf{1}}$ & $\mathbf{X}_{\mathbf{2}}$ & $\mathbf{\sigma}_{\mathbf{2}}$ \\
\hline battle march 12km, min, sec & 60.2 & 2.83 & 55,44 & 2,5 \\
obstacle course, min, sec & 3.2 & 0.09 & 3,09 & 0.07 \\
complex power exercise (4 exercises), min & 3.5 & 0.03 & 3,35 & 0.03 \\
fire preparation, min, sec & 1.52 & 0.21 & 1,49 & 0.19 \\
firing (AK-1, PM), from 250 points & 164.17 & 15.83 & 174,0 & 14,4 \\
\hline
\end{tabular}

low in comparison with the standards used at selection of servicemen in divisions of a special appointment of the countries, participants of the North Atlantic Alliance. At the same time dynamics of results of run on $10 \mathrm{~km}$ demonstrates a reliable increase in the level of functionality of servicemen by the end of the period of preparation, $\mathrm{p}<0.05$. This gain made $11.5 \%$ in a percentage ratio.

Analyzing indicators of time of overcoming an obstacle course, we noted that by the end of the period of preparation they tend to improvement, $p>0.05$. This gain is rather insignificant $-4.3 \%$ in a percentage ratio.

Initial time of performance of the power block by servicemen was $4.08 \mathrm{~min}$ at the beginning of preparation. The considerable part from this time was spent for performance of 30 bendings extensions of hands in an emphasis lying - till $1.04 \mathrm{~min}$. and turn over of a rubber tire - till $2.04 \mathrm{~min}$. The performance of these elements of the power block for $55 \mathrm{sec}$. and $1.52 \mathrm{~min}$. became available respectively by the end of the period of preparation by the serviceman. Thus, the general time of performance of complex power exercise, $\mathrm{p}<0.01$ authentically improved. The gain made $4.2 \%$.

It is visible from tab. 2 that the average result of grenade throwing at the beginning of the researches exceeded the necessary standard on $30 \mathrm{~m}$. Nevertheless, during preparation cadets systematically performen throwing exercises, and the final result in this test exceeds initial one by $4.1 \%$. However the reliability of differences between initial and totals isn't recorded, $\mathrm{p}>0.05$.

The average value of time of assembly and dismantling of weapon and filling of magazine also improved by the end of the period of preparation by $8,3 \%$, however improvement has no reliable character, $\mathrm{p}>0.05$.

The initial level of regular weapon firing was 140.1 points. During the entire period of preparation the effectiveness of firing increased, being 153.8 points at the intermediate stage of preparation and 164.1 points - at the end. Despite improvement of results of firing, an indicator of dispersion remained the same considerable that speaks about the different level of fire preparation of cadets. The percent of a gain of effectiveness of firing between the final and initial levels made $17.3 \%$.

The level of initial training of servicemen on hand-tohand fight is characterized by uncertainty and constraint of movements, mistakes when performing techniques, considerable expense of time for decision-making.

Results of passing an examination by servicemen on the right to wear the beret with honors are presented in tab. 3. Cadets performed battle march on $10 \mathrm{~km}$ in 55.44 min., having improved result by $7.6 \%$ in comparison with preparation totals. Time of overcoming an obstacle course on average improved on $2 \mathrm{sec}$. and was 3.09 min., improved by $9.9 \%$. The average value of time of performance of complex power exercise decreased till $3.35 \mathrm{~min}$., (8.7\% of a gain). The indicator of time of fire preparation also improved slightly - till $1.49 \mathrm{~min}$. (9.\% of a gain). At examination cadets showed much better results of firing - 174 points from 250 possible ( $6.1 \%$ of a gain).

As it is presented in the program of preparation, the main attention was paid to development of the general endurance as successful overcoming a distance of $12 \mathrm{~km}$ in full equipment is a starting point for performance of other stages of examination. In this regard an increase in a psychological component of endurance was in the course of preparation of one of the main tasks. Considering the program of competitions, run on endurance was carried out in the morning, and against the background of the general exhaustion the whole other work was performed. Finishing in battle march on $10 \mathrm{~km}$ makes $40 \%$ of success in the psychological and physical plan as the serviceman isn't allowed to the following stage in case of not finishing of a distance.

\section{Discussion}

The conducted by us researches can be considered as addition to a number of the scientific conclusions about complexity and versatility of physical training in army [1, $10,12]$. The statement that systematic use of aerobic loads in various environment and different time of day allows to increase chance to perform the set combat mission for the serviceman is justified $[8,9,13,19]$.

We consider that improvement of indicators of time of performance of complex power exercise become possible for two reasons. First, work in full regimentals makes cadets more hardy and strong. Secondly, the directed power work with turn over of a rubber tire allowed to raise not only power conditions of cadets, but also to develop individual technique of performance of this exercise. So, servicemen made a number of mistakes in this power exercise at the beginning of preparation: tried to throw a 
tire by force further that led to its rolling away to the left to the right and loss of time for renewal of the movement in the necessary direction. By the end of preparation servicemen overturned a tire, holding it, and pressed to the earth by force. Thereby, they held the necessary direction of the movement, reduced time for a stop of a rubber tire for the next revolution, preserved forces.

Results of our researches have something in common with data of [20]. Researchers claim that using the program of special power training during 2 months allowed to cause positive changes in the preparedness level of naval cadets. Scientists prove with deep arguments that 14 week course of power and aerobic preparation positively affect anthropometrical indicators, body composition and level of force of the Brazilian peacekeeping contingent [21].

Considering the fact that military weapon firing was a penultimate stage of competitions and was made against the background of considerable physical and emotional exhaustion, results can be considered rather high.

Hand-to-hand fight is the second stage for complexity, traditionally. It is confirmed by data of expert poll of teachers. An indispensable condition of a sparring is fight between the serviceman and the instructor of hand-tohand fight. The sparring shouldn't be slow, the fighter has to conduct active actions Thanks to systematic use of trainings in sparrings at servicemen, the technique of performance of methods of hand-to-hand fight improved, time for decision-making and direct performance of a throw or painful reception decreased. The received results of the research expanded data on features of training of the military personnel for check of tactics efficiency of sparring $[15,17]$.
Our researches allowed reaching a new training level of the military personnel. We connected physical, tactical and fire training in our 3-week training program. It allowed to improve results in comparison with initial and to pass the examination successfully on the right of wearing "The beret with honors".

\section{Conclusions:}

The prompt rates of development and modernization of armed forces and other militarized divisions, in particular the National Guard of Ukraine, equaling on the forces level of NATO, demand the high level of professional and physical preparedness of servicemen. In this regard the program of training of servicemen which are earlier developed and introduced in work morally become outdated and demand improvement. The author's technique of training of servicemen for the qualified examination developed and introduced in practice on the right to wear the beret with honors, allows to train the fighter for performance of the set task in a short interval of time.

Use of the author's technique allowed in 21 days of preparation: significantly to increase the level of aerobic endurance and power abilities of the military personnel , $\mathrm{p}<0.05-0.01$. Fighters could show the improved results of shooting sports and fighting sparring in the conditions of considerable physical and neuroemotional loads which accompanied the whole 3-week course of training. Thus, the level of professional preparedness of cadets for performance of the set task was increased.

\section{Conflict of interest}

The authors declare no conflict of interest.

\section{References}

1. Roliuk O. Special physical training of intelligence officers. Fizichne vikhovannia, sport i kul'tura zdorov'ia u suchasnomu suspil'stvi, 2016; 1 (33): 57-63. (in Ukrainian)

2. Nazarenko OL, Drobakha GA. Formalization of the task of choosing rational ways to use the formation of the National Guard of Ukraine to stop the mass riots. Chest' $i$ zakon, 2017; 1(60): 38-45. (in Ukrainian)

3. Finogenov Iu.S. Physical education, special physical training and sports. Kiev; 2014. (in Ukrainian)

4. Okipniak DA, Okipniak AS, Zubal' MV. Methodology for the formation of professional competence among future demining specialists. Fizichne vikhovannia, sport i zdorov'ia liudini, 2017; 10: 374-383. (in Ukrainian)

5. Romanchuk SV. Physical training of cadets of military educational institutions of the Land Forces of the Armed Forces of Ukraine. Kiev; 2012. (in Ukrainian)

6. Kanet RE, Hagerty RL, Pacek AC. Green-berets, seals and spetsnaz - united-states and soviet special military operations - Collns, JM. Osteuropa.1988; 38 (11): 1030-1048.

7. Barclay K, Myrskylä M. Birth order and physical fitness inearly adulthood: Evidence from Swedish military conscriptiondata. Social Science \& Medicine. 2014; 123:141- 148. https://doi.org/10.1016/j.socscimed.2014.11.007

8. Maric L, Krsmanovic B, Mraovic T, Gogic A, Sente J, Smajic M. The effectiveness of physical education of the military academy cadets during a 4-year study. Vojnosanitetski pregled. 2013;70(1):16-20. https://doi.org/10.2298/VSP1301016M

9. Foulis SA, Redmond JE, Frykman PN, Warr BJ, Zambraski EJ, Sharp MA. U.S. Army Physical Demands Study: Reliability of Simulations of Physically Demanding Tasks Performed by Combat Arms Soldiers. Journal of Strength and Conditioning Research. 2017;31(12):3245-52. https://doi.org/10.1519/JSC.0000000000001894

10.Hall LJ. Relationship between 1.5-mile run time, injury risk and training outcome in British Army recruits. Journal of the Royal Army Medical Corps. 2017 Dec;163(6):376-82. https://doi.org/10.1136/jramc-2016-000756

11.Friedl KE, Knapik JJ, Häkkinen K, Baumgartner N, Groeller $\mathrm{H}$, Taylor NAS, et al. Perspectives on Aerobic and Strength Influences on Military Physical Readiness: Report of an International Military Physiology Roundtable. Journal of Strength and Conditioning Research. 2015;29:S10-23. https://doi.org/10.1519/JSC.0000000000001025

12.Kraemer WJ, Vescovi JD, Volek JS, Nindl BC, Newton RU, Patton JF, et al. Effects of Concurrent Resistance and Aerobic Training on Load-Bearing Performance and the Army Physical Fitness Test. Military Medicine. 2004;169(12):994-9. https://doi.org/10.7205/MILMED.169.12.994

13.Anokhin IeD. Overcoming obstacles. Lviv; 2006. (in Ukrainian) 
14.Gdonteli Krinanthi. Investigation of the obstacle course performance at the Hellenic Military Academy. Journal of Physical Education and Sport. 2015; 15(2): 305 - 309. https://doi.org/10.7752/jpes.2015.02046.

15.Ilnytskyy I, Okopnyy A, Palatnyy A, Pityn M, Kyselytsia O, Zoriy Y. Use of boxing to improve the physical education content in lyceums with intensive military and physical training. Journal of Physical Education and Sport. 2018; 18(1): 262 - 269. https://doi.org/10.7752/jpes.2018.01035.

16.Kuznetsov Maksim. A physical quality improvement of special operations force candidates by means of a proprietary program. Slobozans'kij naukovo-sportivnij visnik. 2017; 3(59): 60-65.

17.Ashkinazi SM, Kochergin AN. Analysis of the effectiveness of various tactical variants of close combat. Uchenye zapiski universiteta im. P.F. Lesgafta, 2008; 3: 10-13. (in Russian)
18.Meyer VM. Sport Psychology for the Soldier Athlete: A Paradigm Shift. Military Medicine. 2018;183(7-8):e270-7. https://doi.org/10.1093/milmed/usx087

19.Plyushch MO. Pedagogical Methods of control of endurance of cadets of educational institutions DSNS Ukraine. Theory and methods of physical education. 2016; 2: 16-20.

20. Vantarakis A, Chatzinikolaou A, Avloniti A, Vezos N, Douroudos II, Draganidis D, et al.A2-MonthLinear Periodized Resistance Exercise Training Improved Musculoskeletal Fitness and Specific Conditioning of Navy Cadets. Journal of Strength and Conditioning Research. 2017;31(5):1362-70. https://doi.org/10.1519/JSC.0000000000001599

21.Rosa SE da, Martinez EC, Marson RA, Fortes M de SR, Fernandes Filho J. Military physical training, muscular strength, and body composition of brazilian military personnel. Revista Brasileira de Medicina do Esporte. 2018;24(2):153-6. https://doi.org/10.1590/1517-869220182402169528

\section{Information about the authors:}

Anatskyi R.V.; http://orcid.org/0000-0002-5662-9903; sfp18@ukr.net; The National Academy of the National Guard ofUkraine; Maidan Zakhisnikiv Ukraine 3, Kharkov, 61001, Ukraine.

Kolomiitseva O.E.; (Corresponding author); http://orcid.org/0000-0003-4463-5027; kolomiitseva7@ukr.net; Yaroslav Mudryi National Law University; Pushkinskaya street, 77, Kharkov, 61024, Ukraine.

Liubchich R.E.; http://orcid.org/0000-0002-4429-4288; safarov.87@ukr.net; The National Academy of the National Guard of Ukraine; Maidan Zakhisnikiv Ukraine 3, Kharkov, 61001, Ukraine.

Cite this article as: Anatskyi RV, Kolomiitseva OE, Liubchich RE. The program of physical training of servicemen to a qualification examination on the right to wear the "Beret with honors". Physical education of students, 2018;22(6):285-291. doi:10.15561/20755279.2018.0601

The electronic version of this article is the complete one and can be found online at: http://www.sportedu.org.ua/index.php/ PES/issue/archive

This is an Open Access article distributed under the terms of the Creative Commons Attribution License, which permits unrestricted use, distribution, and reproduction in any medium, provided the original work is properly cited (http:// creativecommons.org/licenses/by/4.0/deed.en).

Received: 12.10 .2018

Accepted: 16.11.2018; Published: 26.12.2018 